\title{
Seasonal effects of wastewater to the water quality of the Caeté river estuary, Brazilian Amazon
}

\author{
LUCI C.C. PEREIRA ${ }^{1}$, MARCELA C. MONTEIRO ${ }^{1}$, DANIELlY O. GUIMARÃES ${ }^{1}$, \\ JISLENE B. MATOS ${ }^{2}$ and RAUQUÍRIO M. DA COSTA ${ }^{2}$ \\ ${ }^{1}$ Laboratório de Oceanografia Costeira e Estuarina, Instituto de Estudos Costeiros, Universidade Federal do Pará, \\ Alameda Leandro Ribeiro, s/n, Aldeia, 68600-000 Bragança, PA, Brasil \\ ${ }^{2}$ Laboratório de Plâncton e Cultivo de Microalgas, Instituto de Estudos Costeiros, Universidade Federal do Pará, \\ Alameda Leandro Ribeiro, s/n, Aldeia, 68600-000 Bragança, PA, Brasil
}

Manuscript received on August 1, 2008; accepted for publication on July 8, 2009

\begin{abstract}
Bragança's socioeconomic situation is highly dependent on estuarine and marine biological resources that are influenced by tidal cycles and climatology. Field measurements (hydrological, hydrodynamic and microbiological variables) were taken in the most urbanized zone from Caeté estuary to characterise the quality of the local environment. During the dry period, the estuary was more eutrophic and presented the highest temperature $\left(30.5^{\circ} \mathrm{C}\right.$ in Oct./06), salinity (17 psu in Feb./07), pH (8.24 in Feb./07) and fecal coliform (>1000 MPN/100 ml in Dec./06 and Feb./07) values. The phytoplankton Cyclotella meneghiniana, Coscinodiscus centralis and other r-strategist species were observed. The lack of basic hydric canalization was responsible for the local contamination, especially during the dry period when more concentrated wastewater from the city was emitted into the estuary, showing the human influence on the reduction of local estuarine water quality. In Bragança, the fishery is considered one of the main economic activities so, this contamination is worrisome because a large part of the local economy depends on biological resources and, thus, the contamination could negatively affect the environmental health of this Amazon ecosystem.
\end{abstract}

Key words: Equatorial estuary, temporal variation, eutrophication, northern Brazil.

\section{INTRODUCTION}

The coastal zone is a transitional region between the continent and the marine environment, and in tropical areas it presents some of the most valuable and productive ecosystems of the world (e.g. mangrove forest and estuaries). However, many changes are taking place within the coastal landscape as a result of population growth and rapid urbanization (e.g. Lozano et al. 2005, Steffy and Kilham 2006, Pereira et al. 2007a).

In the last decades, some social and environmental problems have emerged in the coastal zones worldwide, due to rapid urban development including industrial, port, commercial, agriculture, aquaculture, fish-

Correspondence to: Luci Cajueiro Carneiro Pereira E-mail: cajueiro@ufpa.br eries and tourism activities. These activities need efforts to conserve and recover the productivity of coastal resources and water quality, as well as to improve the health of coastal communities (Linton and Warner 2003, Burak et al. 2004, Chen et al. 2005, Lau 2005).

The Brazilian Amazon represents about $35 \%$ of the country's 8,500 km long coastline (Isaac and Barthem 1995 ), and $85 \%$ of the mangroves in Brazil are found in this section of coastline. The mangroves in the Brazilian Amazon coast represent the second largest continuous worldwide mangrove system on the planet (Lara 2003).

Located in the northeastern state of Pará, Bragança is one of the most important cultural and historical cities in the Amazon littoral. The local socioeconomic situation is directly dependent on biological resources, which 
are influenced by macrotidal cycles and climate (Glaser and Diele 2004, Souza Filho et al. 2006, Barbosa et al. 2007, Pereira et al. 2007b). The lack of public services is also responsible for some of the environmental problems observed in the Caeté estuary, which is the main estuary of this county (Guimarães et al. 2009). The aim of this study was to characterise the water quality and the aim at the effects of human urbanization practices on the environmental status of this Amazon estuary.

\section{STUDY AREA}

The Bragantinian coastal plain is located between the Maiaú and Caeté river bays $\left(00^{\circ} 46^{\prime}-1^{\circ} 00^{\prime} \mathrm{S}\right.$ and $46^{\circ} 36^{\prime \prime}$ $46^{\circ} 44^{\prime} \mathrm{W}$, Cohen et al. 2004). Bragança represents the third most productive fishing area in the State of Pará and its main harbours are located in the Caeté estuary, which includes the city's main river (Silva et al. 2006, Guimarães et al. 2009) (Fig. 1).

The regional climate in the studied area is equatorial humid with two main seasons, a rainy and a dry period. The rainy period, which normally occurs between January and June, is characterised by a mean rate of rainfall exceeding $2,200 \mathrm{~mm}$ and temperature values up to $30^{\circ} \mathrm{C}$. On the other hand, the dry period, which occurs between July and December, presents higher insolation and evaporation rates, a mean rainfall of 100-200 $\mathrm{mm}$ and temperature values up to $32^{\circ} \mathrm{C}$. The wind also has a seasonal pattern, with the strongest winds occurring during the dry season, and more moderate winds occurring during the rainy period (Martorano et al. 1993, Lara 2003).

The area's tides are semidiurnal with a maximal tidal height between 4 and $6 \mathrm{~m}$. Tidal currents usually reach higher values $\left(\sim 1.5 \mathrm{~m} . \mathrm{s}^{-1}\right)$ during the equinoccial spring tides (Cohen et al. 1999).

About 57,000 people live in Bragança's urban area and the local economy is based on fisheries, commerce, agriculture and tourism (IBGE 2003).

\section{METHODS}

Precipitation data were furnished by a meteorological station from the Instituto Nacional de Meteorologia (INMET) located in Tracuateua (about $40 \mathrm{~km}$ from Bragança harbours). Water sampling was carried out bimonthly at one fixed station (Fig. 1), totalizing of one year of sampling collection on the waterfront of Bragança. Each sampling was performed during spring tides over a 24h-period near the city's main harbour (located approximately $36 \mathrm{~km}$ from the Atlantic Ocean and therefore at the upper estuary, according to Barletta et al. 2005) between April/2006 and February/2007. During each sampling period, physical (tide and currents, measured at every $10 \mathrm{~min}$ ), chemical (hydrological data, collected at every $6 \mathrm{~h}$ ) and biological (microphytoplankton and fecal coliform, collected at every $6 \mathrm{~h}$ ) variables were measured in the sub-surface water (0-3 $\mathrm{m}$ depth). The water transparency was measured using a Secchi disc between 10 am and $14 \mathrm{pm}$.

Hydrological and microbiological data $(\mathrm{pH}$, dissolved oxygen, dissolved nutrients, chlorophyll $a$ and fecal coliform) were obtained from the analysis of water samples collected with Niskin oceanographic bottles. Water salinity and temperature were obtained using a CTD (XR-420, RBR). Sub-surface current speeds were measured using a Sensordata SD6000 current metre. The variation in local water levels was simultaneously surveyed using a graduated pole fixed in Bragança's harbour. Additional sub-surface samples were collected with a plankton net with a mesh size of $64 \mu \mathrm{m}$ to characterise microphytoplankton composition. Field and laboratory studies followed methodologies used by the American Public Health Association (2004) and other analytic manuals (e.g. Strickland and Parsons 1968, 1972, Grasshoff et al. 1983). The floristic composition was assessed by identifying specific and infra-specific taxa using specialized bibliography (Cupp 1943, Sournia 1975, Ricard 1987, Tomas 1997).

The main human activities that affect direct or indirectly the water quality of this estuary were observed around the studied area.

The normality and homogeneity of hydrological data (salinity, temperature, $\mathrm{pH}$, dissolved oxygen, dissolved nutrients such as nitrite, nitrate, phosphate and chlorophyll a) were tested using Lilliefors (Conover 1971) and Bartlett's Chi-square tests (Sokal and Rohlf 1969), respectively, in the STATISTICA 6.0 package (StatSoft 2001). When the analysed data were not normal, $\log (x+1)$ transformations were performed to achieve near-normal distributions, and one-way ANOVA tests were used to find differences in the hydrological 


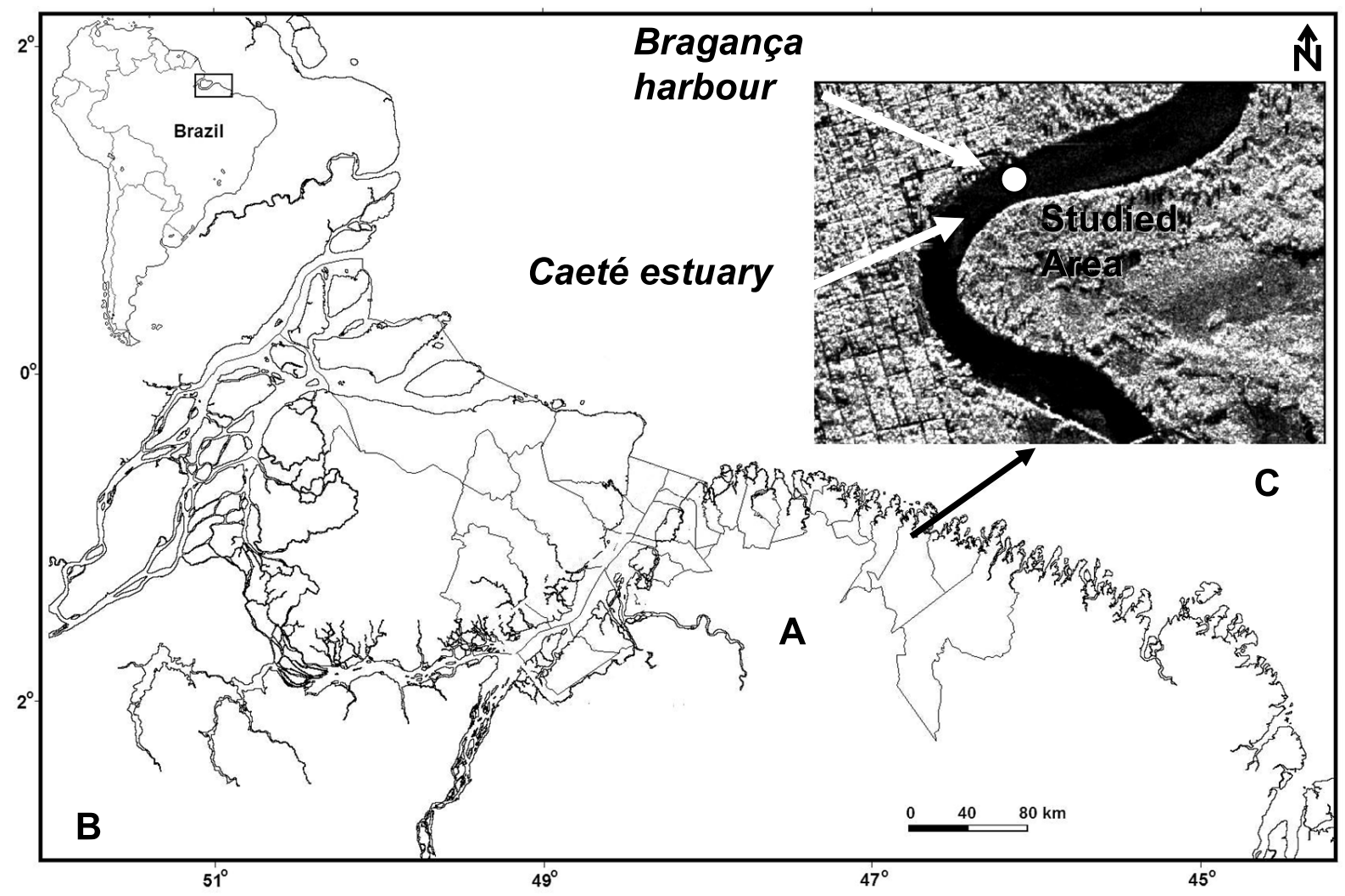

Fig. 1 - Pará State coastal area (A) (made by Souza-Filho), Northern of Brazil (B) and Bragança harbour with the position of the sampling station $(\mathrm{C})$.

parameters between seasonal periods with a significance level of 0.05 . However, when the variances were heterogeneous, a non-parametric Mann-Whitney $U$-test was applied (Zar 1999) using the same significance level referred to above (0.05).

\section{RESULTS}

The Caeté estuary is strongly affected by human activities in several different ways. The lack of basic hydric canalization in Bragança city, for example, affects the water quality of this estuary, particularly in the more urbanised zones where the most concentrated domestic, hospital and commercial sewage is emitted daily. In addition, on the waterfront of the city there are public markets, fishery harbours and ice factories that contribute directly to organic and inorganic contamination of the Caeté estuary.

Physical, chemical and biological data showed strong seasonal variations due to the very well-defined climatic seasonal structure. The regional climate in the studied area is highly seasonal with two main seasons, dry and rainy. During the studied period, the dry period occurred from July/06 to February/07, characterised by a rainfall rate of $384.5 \mathrm{~mm}$. The rainy period comprised January/06 until June/06 and was characterised by a rainfall rate of $2,363.1 \mathrm{~mm}$. Constant and strong winds were registered during the dry period (in general higher than $>4 \mathrm{~m} . \mathrm{s}^{-1}$ ), while strong gusts were observed during the rainy period.

Hydrodynamic data showed a predominance of high energy conditions during the year, which were characterised by stronger currents as a consequence of the elevated wind intensities (during the dry period) and high rainfall rates (during the rainy period). The maximal variation of the water level was $4.8 \mathrm{~m}$ in December/06 (strong winds) and the maximal tidal current was higher than $1.2 \mathrm{~m} . \mathrm{s}^{-1}$ in April/06 (equinoccial spring tide). During the rainy period, maximal tidal currents (Fig. 2) were observed mainly during the ebb tide due to an increased outflow of the Caeté estuary. During the 
dry period, the highest tidal current intensities (Fig. 2) were observed during the flood tide, possibly as a consequence of strong winds and due to the decrease in the Caeté river outflow.

During the rainy period, salinity values ranged between zero (April and June/06) and 0.60 psu (August/ 06), while the temperature ranged between $26.10^{\circ} \mathrm{C}$ (June/06) and $28.90^{\circ} \mathrm{C}$ (August/06). Values for water $\mathrm{pH}$ ranged between 6.09 (April/06) and 7.63 (August/ $06)$, while water transparency ranged between zero (April/06) and $20 \mathrm{~cm}$ (June/06) due to high suspended particulate material and high nebulosity. Dissolved oxygen concentrations were significantly higher $(\mathrm{F}=12.39$, $\mathrm{p}=0.0019)$ during this period and ranged between $4.10 \mathrm{~m} . \mathrm{L}^{-1}$ (August/06) and $8.40 \mathrm{mg} . \mathrm{L}^{-1}$ (June/06). Chlorophyll $a$ concentrations ranged from $5.06 \mathrm{mg} \cdot \mathrm{m}^{-3}$ (August/06) to $28.09 \mathrm{mg} . \mathrm{m}^{-3}$ (April/06) with slightly higher values during the rainy period, although no significant differences were observed between the studied seasons (Fig. 3). With respect to dissolved nutrient concentrations, the maximum observed values were $0.36 \mu \mathrm{M}$ (in April/06) for nitrite, $14.42 \mu \mathrm{M}$ (in August/06) for nitrate and $0.83 \mu \mathrm{M}$ (in August/06) for phosphate (Fig. 3).

In the dry season, the low rainfall contribution, the low continental freshwater input and high insolation and evaporation rates were responsible for significantly higher values of temperature $(\mathrm{F}=31.73, \mathrm{p}<0.05)$, salinity $(\mathrm{U}=2.00, \mathrm{p}<0.05)$ and $\mathrm{pH}(\mathrm{F}=24.88, \mathrm{p}<0.05)$. Temperatures oscillated between $27.80^{\circ} \mathrm{C}$ (February/ 07) and $30.50^{\circ} \mathrm{C}($ October/06), while salinities values ranged from $0.30 \mathrm{psu}$ (October/06) to $17 \mathrm{psu}$ (February/07). Values for $\mathrm{pH}$ ranged between 7.04 (October/ 06) and 8.24 (February/07). The lowest dissolved oxygen and chlorophyll $a$ concentrations were observed during the dry season and ranged from $3.0 \mathrm{mg} . \mathrm{L}^{-1}$ (December/06) to $7.50 \mathrm{mg} . \mathrm{L}^{-1}$ (February/07) and $3.86 \mathrm{mg} \cdot \mathrm{m}^{-3}$ (October/06) to $19.52 \mathrm{mg} . \mathrm{m}^{-3}$ (February/07) (Fig. 3), respectively. Nitrate and nitrite values were significantly higher during this season $(F=107.01, p<0.05 ; \mathrm{U}=$ $24.00, \mathrm{p}<0.05$, respectively) with maximum respective values of $5.07 \mu \mathrm{M}$ (nitrite- $\mathrm{NO}_{2}$, December/06) and $59.35 \mu \mathrm{M}$ (nitrate- $\mathrm{NO}_{3}$, February/07). Phosphate- $\mathrm{PO}_{4}$ concentrations, which reached a maximum value of $6.60 \mu \mathrm{M}$ in October/06, did not differ between seasons (Fig. 3).
Fecal coliform data showed that the maximum values also occurred during the dry season (>1100 MPN/ $100 \mathrm{ml}$ ) in December/06 and February/07, while the lowest values were observed during the rainy period (110 MPN/100 ml) in April/06 (Fig. 4).

In the studied area, the micropytoplankton community was made up of 132 taxa, of which $97 \%$ were Bacillariophyta (diatoms). Dinophyta (1.50\%) and Cyanophyta $(1.50 \%)$ were less represented groups.

Diatoms were represented by three classes, nine sub-classes, 20 orders, 34 families and 52 genera. Coscinodiscus Ehrenberg (15 taxa), Nitzschia Hassall (11 taxa) Chaetoceros Ehrenberg (six taxa) were the predominant genera. Five genera of Bacillariaceae and four genera of Triceratiaceae were observed, making these the most frequently-observed families. Well-represented species were Coscinodiscus centralis Ehrenberg, Coscinodiscus concinnus Wm. Smith, Coscinodiscus perforates Ehrenberg, Dimeregramma minor (Gregory) Ralfs, Ditylum brightwellii (West) Grunow, Odontella sinensis (Greville) Grunow, Thalassionema frauenfeldii (Grunow) Hallegraeff, Cyclotella meneguiniana Kützing and Asterionellopsis glacialis (Castracane) Round.

The occurrence of r-strategist species, such as $A s-$ terionellopsis glacialis, Coscinodiscus centralis, Cyclotella meneghiniana and Skeletonema spp., which were mainly observed in the dry periods, suggested local eutrophication.

Dimeregramma minor was the most abundant species, representing between $56 \%$ and $82 \%$ of the total number of cells counted in the samples.

\section{DISCUSSION}

In general, the rainy period in the Pará State comprises the months from January to June, while the dry period occurs during the remaining months of the year (Martorano 1993). However, in the present study, the rainiest months were observed from April to August/2006, while the dry period occurred between the months of September/2006 and February/2007. Due to the delay of the rainy period, it was possible to observe an elevated difference of the hydrological data between April/06 (rainy period) and February/07 (dry period). This pattern of rainfall was also recorded by Moraes et al. (2005), in a study that analysed a historical data series of 23 years 
Current speed $(\mathrm{m} / \mathrm{s})$

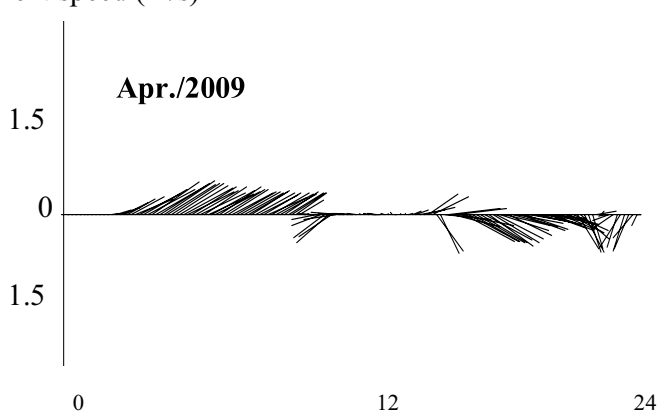

Hours

Current speed $(\mathrm{m} / \mathrm{s})$

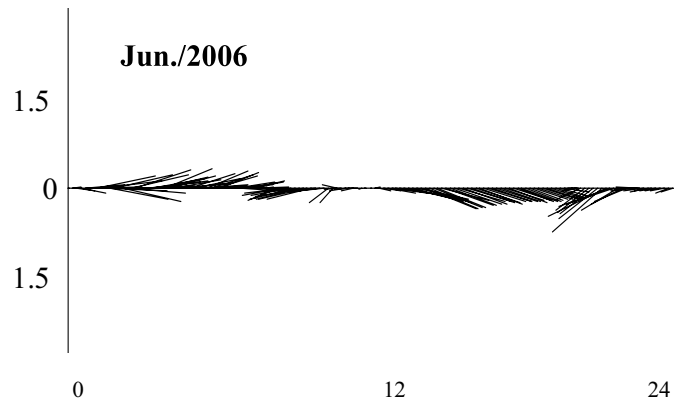

Hours

Current speed (m/s)

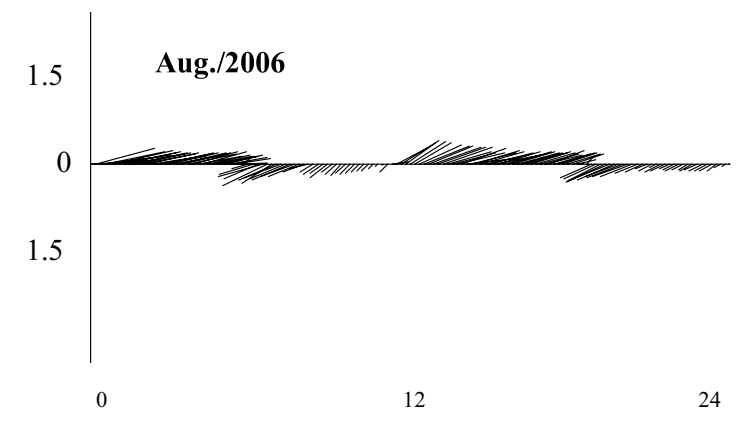

Hours

Current speed $(\mathrm{m} / \mathrm{s})$

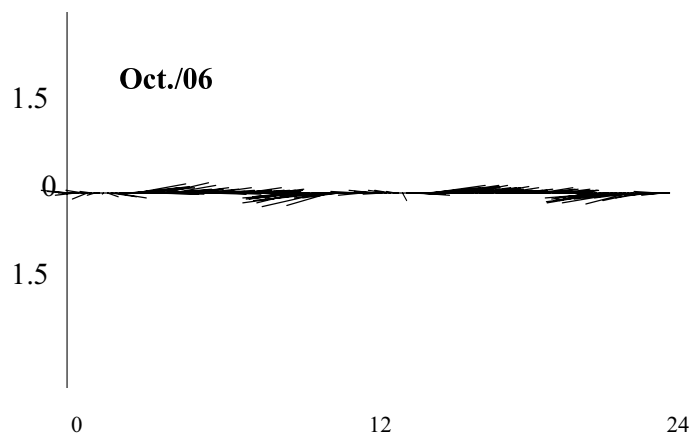

Hours
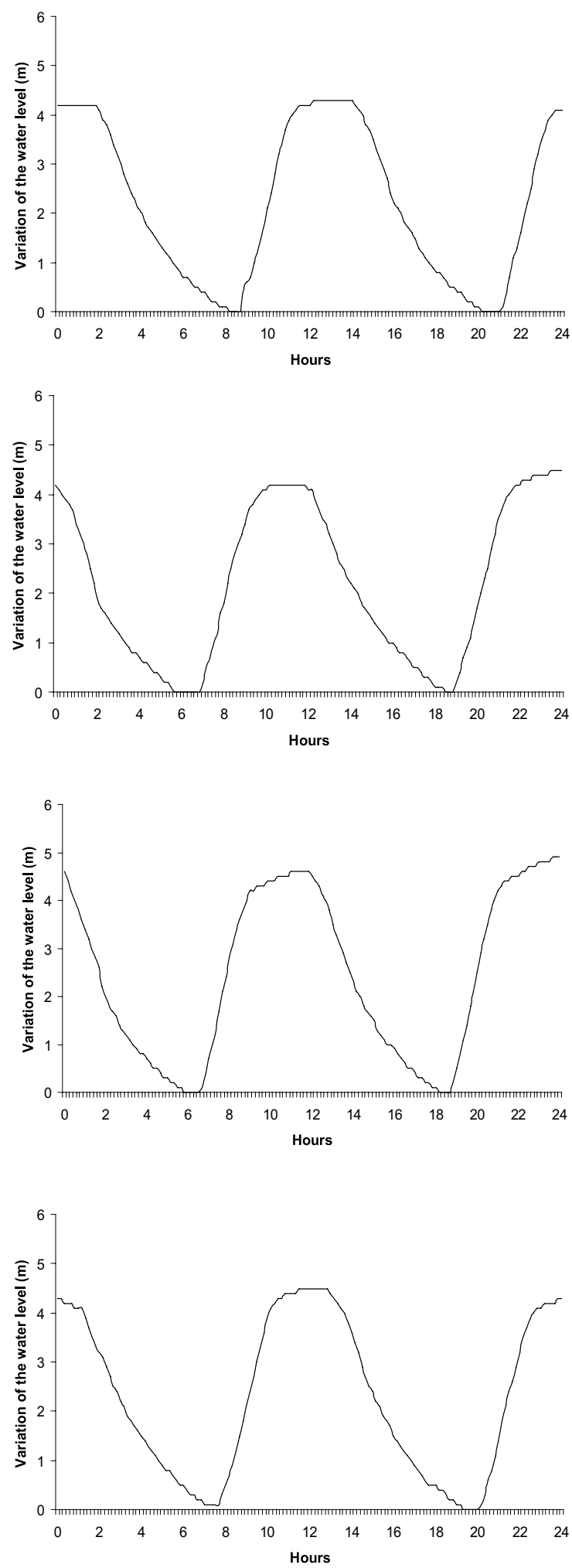

Fig. 2 - Hydrodynamic data recorded between April/06 and February/07, during spring tides, in the Caeté estuary. 
'Current speed $(\mathrm{m} / \mathrm{s})$

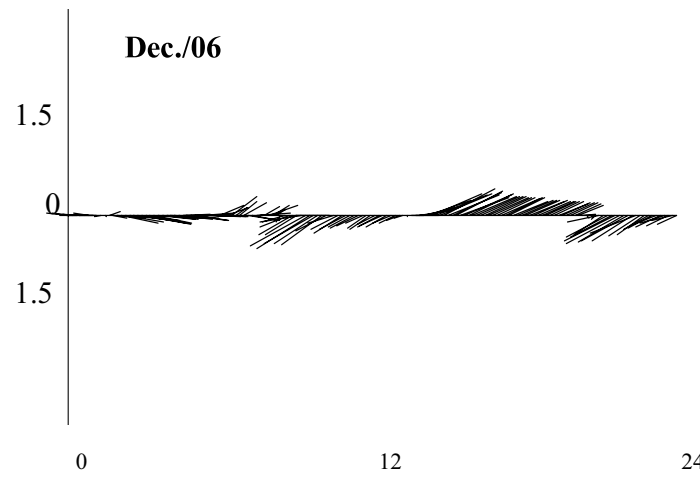

Hours

Current speed $(\mathrm{m} / \mathrm{s})$

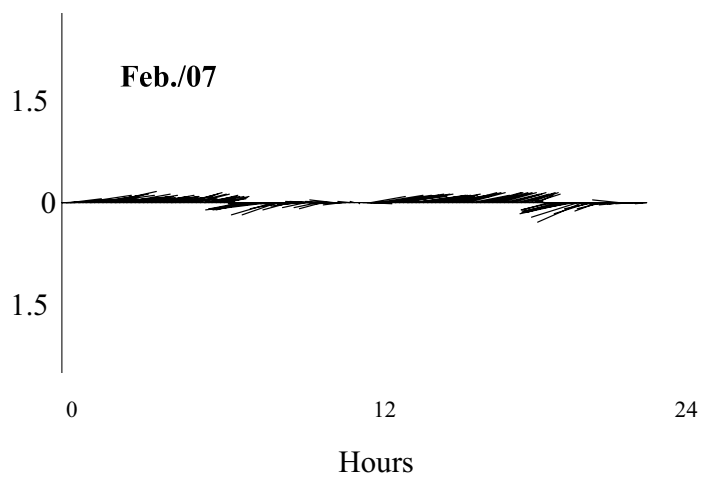

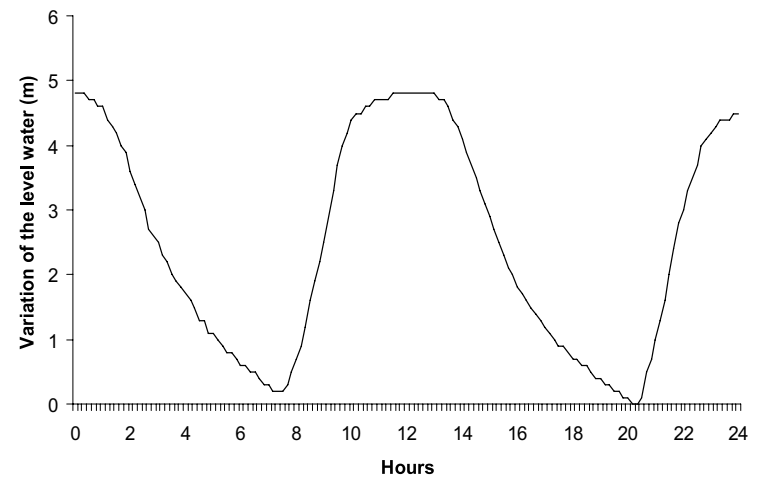

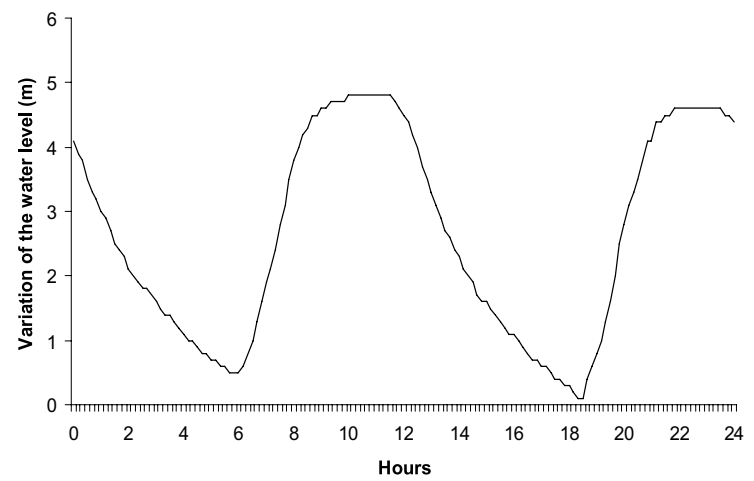

Fig. 2 (Continuation) - Hydrodynamic data recorded between April/06 and February/07, during spring tides, in the Caeté estuary.

(1976-1998) and reported a conspicuous delay in the beginning of the rainy period in the Bragantine zone when compared to other zones of the Pará State.

The strong hydrodynamic regime in the Amazon estuaries is a consequence mainly of macrotidal cycles, high tidal current intensities and strong trade winds (Meade et al. 1985, Figueroa and Nobre 1990, Beardsley et al. 1995, Marengo 1995, Geyer et al. 1996, Monteiro et al. 2009, Pereira et al. 2009).

In the studied area, tidal asymmetry was recorded in the two seasons and the tidal current data showed differences (period and intensity of the tidal currents) between the ebb and flood tides. In the Amazon coastal zone, the mangrove system and creeks, the presence of many estuaries, as well as the occurrence of sand banks, may be responsible for the local tide asymmetry (Mazda et al. 1995, Lam-Hoai et al. 2006, Pereira et al. 2009, Monteiro et al. 2009). Observations of current speed showed that, during the dry period (when the estuarine water is most contaminated and the flood tide current is stronger), the organic contaminants may be transported to the upper part of the Caeté estuary. During the rainy period (when ebb tide currents are stronger), the organic contaminants seem to be transported to the lower part of the estuary. Silva et al. (2006) and Guimarães et al. (2009) showed that organic and inorganic contaminants emitted into the Caeté estuary have affected the environmental quality and human health in the upper part of this estuary.

The high variability in the rainfall rates commonly found in the equatorial zone during the rainy period was responsible for the lowest salinity, temperature and transparency values during this season. In addition, the $\mathrm{pH}$ ranged from slightly acid to alkaline, showing the effects of freshwater input from rainfall and river runoff on estuarine waters. Conversely, the high dissolved oxygen concentrations observed during the rainy period indicated a higher water-atmosphere interaction due to the 

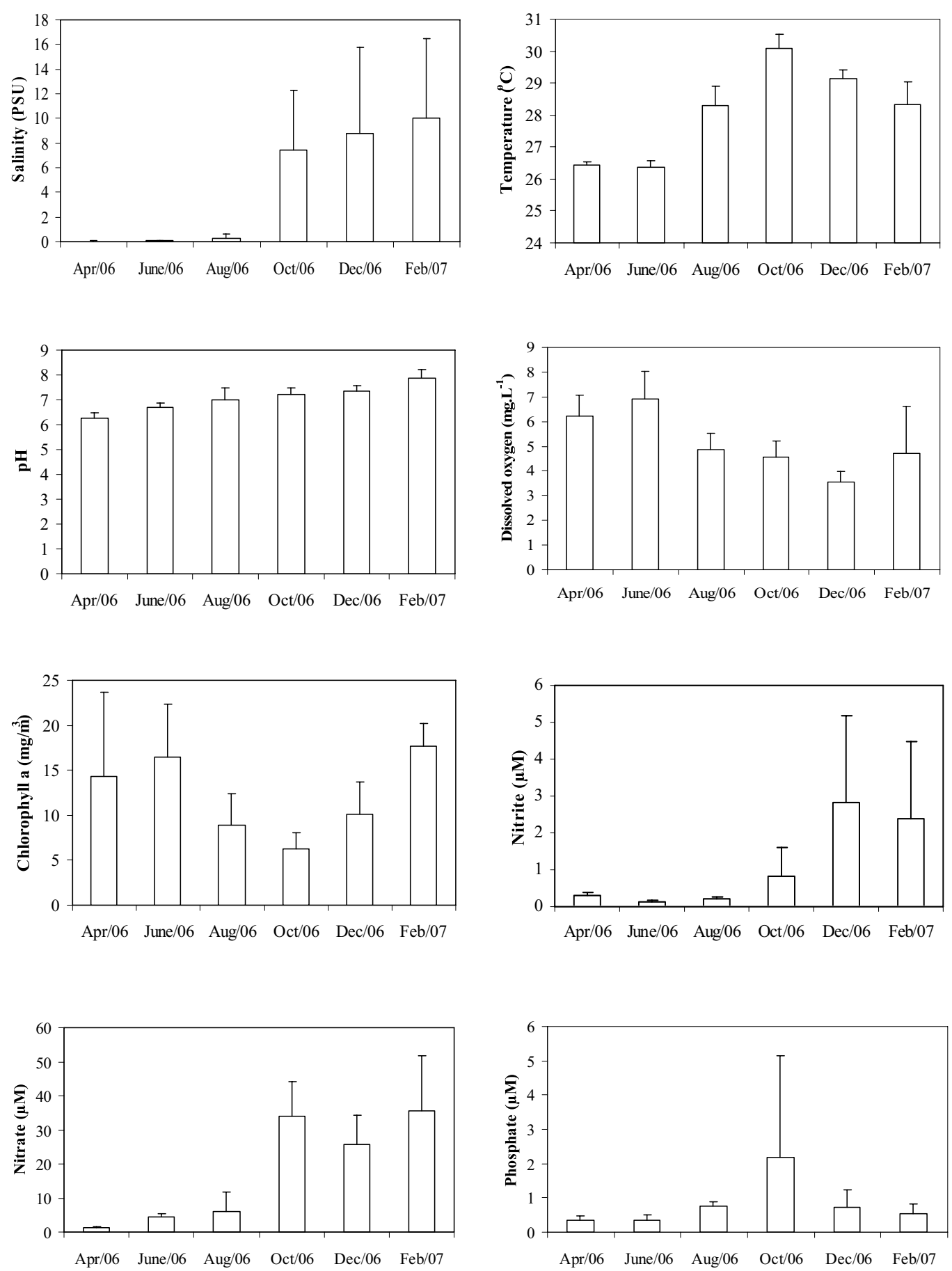

Fig. 3 - Mean hydrological values between April/06 and February/07, in the Caeté estuary.

high local hydrodynamic regime and turbulent mixture that contributed to the presence of highly oxygenated freshwater in the superficial layer. The highest chlorophyll $a$ concentrations (Fig. 3) during the rainy period were also associated with the highest dissolved oxygen concentrations. During the rainy period, urban outfall was diluted as a result of the high pluvial water input and the high river discharges into the Caeté estuary, consequently decreasing the dissolved nutrient concentrations. In addition, the high chlorophyll $a$ concentration (indi- 
cated by the elevated phytoplankton density) may also have contributed to the observed decrease in the nutrient values. In non-stressed coastal zones, the highest nutrient concentrations can be found during the rainy period due to the river run-off, contribute to the occurrence of high chlorophyll $a$ concentrations due to increased phytoplankton biomasses.

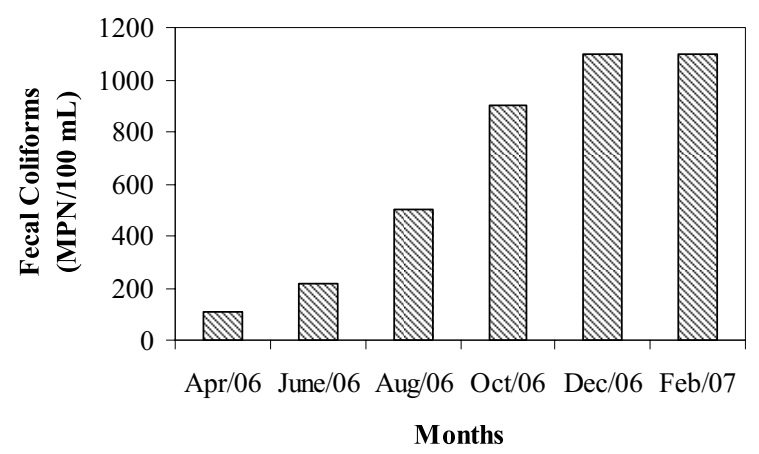

Fig. 4 - Fecal coliform values between April/06 and February/07, in the Caeté estuary.

In the dry season, the $\mathrm{pH}$ remained alkaline, indicating the strong influence of marine waters on the estuary. Alkalinity is also a common feature of coastal Amazon environments, as noted by Martinelli et al. (2002), Costa et al. (2008, 2009), Silva et al. (2009) and Magalhães et al. (2009) in the Maranhão and Pará States. Besides being influenced by dissolved salt content in the water, $\mathrm{pH}$ can be also affected by biological, physical and chemical processes (tidal cycles, respiration and photosynthesis effects, for example). In general, $\mathrm{pH}$ attains elevated values due to the consumption of carbon dioxide by phytoplankton and the consequent liberation of oxygen during elevated photosynthetic activity periods (Flores Montes et al. 1998). However, this was not observed in the studied area. The lowest dissolved oxygen concentrations registered in this season are possibly related to the lowest observed photosynthetic activity (low chlorophyll $a$ concentrations). In addition, the highest dissolved nutrient concentrations recorded during this season may be attributed to the input of more concentrated domestic and commercial sewage into the Caeté estuary. The low estuarine depths (up to $10 \mathrm{~m}$ in the high spring tide) and the high water column mixture (as a consequence of the strong winds in the second half of the year and of the occurrence of equinoccial spring tides between September and October) were also responsible for the re-suspension of nutrients from the bottom during the second semester.

The discharge of domestic, medical and commercial sewage concentrates, as well as of others organic and inorganic contaminants from public markets, fishery ports, ice factories and the Cereja River also contribute to the contamination of the Caeté estuary in the studied sector (Gorayeb et al. 2006, Guimarães et al. 2009). During the dry season, the input of more concentrated domestic and commercial sewage into the Caeté estuary contributed to the highest fecal coliforms values observed. On the other hand, the lowest fecal coliform values were registered in April/06 due to the dilution of urban outfalls as a consequence of the high rainfall rate and the occurrence of an equinoccial spring tide (high tidal height and strong currents).

In equatorial and tropical zones, the rainfall patterns and some human activities (e.g., lack of an efficient sanitary system, lack of urban cleanness, factories and harbour activities) are responsible for controlling physical-chemical variables, and consequently the abundance, distribution and diversity of different estuarine organisms (Koening et al. 2003, Lam-Hoai et al. 2006, Silva et al. 2009).

Planktonic organisms make up the base of estuarine and marine food webs and perform key functions in transforming the chemical and physical forms of nutrients and contaminants and transporting these materials to higher trophic levels (Thompson et al. 2007). As a result, these organisms have a high value as biological indicators of water quality due to their high growth rates in response to abiotic and biotic oscillations (Day et al. 1989, Espino et al. 2000, Gómez and Licursi 2001). Species that indicate environmental eutrophication were observed by Lacerda et al. (2004) and Pereira et al. (2005) in contaminated urban areas, showing the high nutrient assimilation efficiency of these organisms (Smetacek 1998).

The predominance of diatoms in coastal waters is reported worldwide (Tilstone et al. 2000, Gin et al. 2000, Huang et al. 2004, Eskinazi-Leça et al. 2004, Örnólfsdóttir et al. 2004, Sousa et al. 2008), and indicates their ability to adapt to non-stratified, turbulent (Smayda 1980, Tilstone et al. 2000, Smayda 2002) and nutrient-enriched waters (Tundisi 1970) such as those 
observed in the studied area.

The occurrence of macrotidal regimes (high energy) in the Amazon littoral zone and the high turbulent mixture and bottom sediment re-suspension could contribute to the presence of phytobenthonic species in the pelagic environment (Sousa et al. 2008). In the studied area, the high hydrodynamic regime contributed to the presence of tychoplanktonic species in the water column, such as Dimeregramma minor that was the most abundant species found during both seasons.

\section{CONCLUSION}

Regional climatic conditions, the macrotidal regime and human-induced activities combine to control the water characteristics in the studied area. The lack of basic hydric canalization was mainly responsible for the contamination in the Caeté estuary. This was particularly true during the dry period, when more concentrated domestic and commercial sewage was emitted into this estuary and when the highest number of r-strategist species was found. This observation is concerning because a large part of the local economy depends on the biological resources of the estuary and its contamination could negatively affect the environmental health of this Amazon estuarine ecosystem in the near future.

Government authorities should improve local services by constructing a sanitary collection system, offering an efficient urban cleanness, controlling market, medical and ice factory garbage disposal and constructing an efficient sewage treatment plant to promote the treatment of sewage, as well as to control the wastewater input into the Caeté estuary in order to mitigate the observed problems.

\section{ACKNOWLEDGMENTS}

This study is a product of the CT-AGRO Project n. 552760/2005-6 and Universal Project n. 473097/20036 supported by Conselho Nacional de Desenvolvimento Científico e Tecnológico $(\mathrm{CNPq})$. The authors Pereira and Costa would like to thank CNPq (Brazil) for their research grants.

\section{RESUMO}

A situação socioeconômica de Bragança depende principalmente dos recursos biológicos estuarinos e marinhos, que são influenciados pelos ciclos de marés e climatologia. Coletas oceanográficas (com medidas de variáveis hidrológicas, hidrodinâmicas e microbiológicas) foram realizadas na área mais urbanizada do estuário do Caeté, para caracterizar a qualidade das águas no setor estudado. Durante o período seco, o estuário foi mais eutrófico e apresentou os maiores valores de temperatura $\left(30,5^{\circ} \mathrm{C}\right.$ em Out./06), salinidade (17 psu em Fev./07), $\mathrm{pH}(8,24 \mathrm{em} \mathrm{Fev./07)} \mathrm{e} \mathrm{coliformes} \mathrm{fecais} \mathrm{(>1000}$ MNP/ $100 \mathrm{ml}$ em Dez./06 e Fev./07). As espécies fitoplanctônicas Cyclotella meneghiniana, Coscinodiscus centralis e outras espécies r-estrategistas também foram observadas. A falta de saneamento básico foi responsável pela contaminação local, especialmente durante o período seco, quando o esgoto foi lançado mais concentrado no estuário, mostrando a influência humana na redução da qualidade da água estuarina estudada. A pesca é considerada uma das principais atividades econômicas do município de Bragança e, portanto, esta contaminação poderá afetar negativamente a qualidade ambiental deste ecossistema amazônico.

Palavras-chave: Estuário equatorial, variação temporal, eutrofização, norte do Brasil.

\section{REFERENCES}

American Public Health Association. 2004. Standard Methods for Examination of Water and Wastewater. Washington, D.C. $<$ http://www.standard.methods.org/Articles.cfm > .

Barbosa VM, Gregório AM da S, Busman DV, CosTA RAAM DA, Sousa FILHO PW DE AND PEREIRA LCC. 2007. Estudo morfodinâmico durante uma maré equinocial de sizígia em uma praia de macromaré do Litoral Amazônico (Praia de Ajuruteua - PA, Brasil). Bol Paranaense de Geoc 60-61: 31-43.

Barletta M, Barletta-Bergan AB and Saint-Paul USGH. 2005. The role of salinity in structuring the fish assemblages in a tropical estuary. (available on line). J Fish Biol 66: 45-72.

Beardsley RC, Candela J, Limeburner R, Geyer WR, Lentz SJ, CAstro BM, CACChione D AND CARneiro N. 1995. The M2 tide on the Amazon shelf. J Geophy Res 100 (C2): 2283-2319.

Burak S, Dogan E And Gazioglu C. 2004. Impact of 
urbanization and tourism on coastal environment. Ocean Coast Manage 47: 515-527.

Chen S, Chen L, Liu Q, Li X and Tan Q. 2005 . Remote sensing and GIS-based integrated analysis of coastal changes and their environmental impacts in Lingding Bay, Pearl River Estuary, South China. Ocean Coast Manage 48: 65-83.

Cohen MCL, Lara RJ, Ramos JFF and Dittmar T. 1999. Factors influencing the variability of $\mathrm{Mg}, \mathrm{Ca}$ and $\mathrm{K}$ in waters of a mangrove creek, in Bragança, North Brazil. Mang Salt Marsh 44: 1-7.

Cohen MCL, Souza Filho PWM, LARA RJ, Behling H AND ANGUlo RJ. 2004. A model of Holocene mangrove development and relative sea-level changes on the Bragança Peninsula (Northern Brazil). Wetlands Ecol Manag 13: 433-443.

CONOVER WOJ. 1971. Practical nonparametric statistics. J Wiley \& Sons, New York, USA, 462 p.

Costa KG, Pereira LCC and Costa RM da. 2008. Short and long-term temporal variation of the zooplankton in a tropical estuary (Amazon region, Brazil). Bol Mus Para Emílio Goeldi, Ser Cienc Nat 3: 127-141.

Costa RM DA, Leite NR AND Pereira LCC. 2009. Mesozooplankton of the Curuçá Estuary (Amazon Coast, Brazil). J Coastal Res SI56: 4000-404.

Cupp ED. 1943. Marine plankton diatoms of the West Coast of North America. Bull Scrips Inst Oceanogr Univ Calif La Jolla 5: 1-238.

DAY JW, Hall CAS, Kemp WM And YaneZ-ARAnCiBia A. 1989. Estuarine ecology. J Wiley \& Sons, Interscience Publication, New York, USA, 577 p.

Eskinazi-LeÇA E, KoEning ML and Silva-CunHA MGG. 2004. Estrutura e dinâmica da comunidade fitoplanctônica. In: ESKINAZI-LEÇA E, NEWMANN-LEITÃo AND CosTA MF (Orgs), Oceanografia: um cenário tropical, $1^{\mathrm{a}}$ ed., Recife, Edições Bagaço, p. 353-373.

EsPino GL, Pulido SH ANd PÉREZ JLC. 2000. Organismos indicadores de la calidad del agua y de la contaminación (bioindicadores) México: Plaza y Valdés S.A., $633 \mathrm{p}$.

Figueroa SN and Nobre CA. 1990. Precipitations distribution over Central and Western Tropical South American. Climanálise. Bol Monitor Anal Clima 5: 36-45.

Flores Montes MJ, Macêdo SJ, Koening ML AND LINS IC. 1998. Variação nictemeral do fitoplâncton e elementos nutrientes no Canal de Santa Cruz, Itamaracá -
PE - Brasil. Trabalhos Oceanográficos da Universidade Federal de Pernambuco 26: 13-26.

Geyer WR, Beardsley RC, Lentz SJ, Candela J, Limeburner R, Johns WE, CAstro BM And SoARES ID. 1996. Physical oceanography of the Amazon shelf. Cont Shelf Res 16: 575-616.

Gin KYH, Lin X And Zhang S. 2000. Dynamics and size structure of phytoplankton in the coastal waters of Singapore. J Plankton Res 22: 1465-1484.

Glaser M AND Diele K. 2004. Asymmetric outcomes: assessing central aspects of the biological, economic and social sustainability of a mangrove crab fishery, Ucides cordatus (Ocypodidae), in North Brazil. Ecol Econ 49: 361-373.

Gómez N And Licursi M. 2001. The Pampean Diatom Index (IDP) for Assessment of Rivers and Streams in Argentina. Aquatic Ecology 35: 173-181.

Gorayeb A, Lima ST And Pereira LCC. 2006. Análise Integrada e da degradação ambiental na bacia hidrográfica do Rio Caeté, NE do Pará, Brasil. In: VI SEMINÁRIO DE Pós-GRAduAÇÃo EM Geografia da UNESP, Rio Claro, CD-ROM, p. 24-41.

Grasshoff K, Emrhardt M AND Kremling K. 1983. Methods of Seawater Analysis. Verlag Chemie, New York, USA, 419 p.

Guimarães D de O, Pereira lCC, Monteiro MC, Gorayeb A And Costa RM. 2009. Effects of the urban influence on the Cereja River and Caeté Estuary (Amazon littoral, Brazil). J Coastal Res SI56: 1219-1223.

Huang L, Jian W, Song X, Huang X, LiU S, Qian P, YIN K AND WU M. 2004. Species diversity and distribution for phytoplankton of the Pearl river estuary during rainy and dry seasons. Mar Pollution Bull 49: 88-596.

Instituto Brasileiro de Geografia e Estatística (IBGE). 2003. Censo Demográfico.

$<$ http://www.ibge.gov.br>.

ISAAC VJ AND BARTHEM RB. 1995. Os Recursos pesqueiros da Amazônia brasileira. Bol Mus Para Emílio Goeldi Ser Zool 11(2): 151-194.

Koening ML, LeÇA EE, LeItão SN And MACEdo SJ. 2003. Impacts of the construction of the Port of Suape on the phytoplankton community in the Ipojuca River Estuary. Braz Arch Biol Techn 46: 73-81.

LACERdA SR, Koening ML, Leitão SN ANd Montes MJF. 2004. Phytoplankton nyctemeral variation at a Tropical River Estuary (Itamaracá - Pernambuco - Brazil). Braz J Biol 64: 81-94. 
LAm-Hoai T, Guiral D And Rougier C. 2006. Seasonal change of community structure and size spectra of zooplankton in the Kaw River Estuary (French Guiana). Estuar Coast Shelf S 68(1-2): 47-61.

LARA RJ. 2003. Amazonian mangroves - A multidisciplinary case study in Pará State, North Brazil: Introduction. Wetlands Ecol Manag 11: 217-221.

LAU M. 2005. Integrated coastal zone management in the People's Republic of China. An assessment of structural impacts on decision-making processes. Ocean and Coast Manage 48: 115-159.

LINTON DM AND WARNER GF. 2003. Biological indicators in the Caribbean coastal zone and their role in integrated coastal management. Ocean and Coast Manage 46: 261276.

LozAno LO, BARba GA, Weiss SV AND SALGado GMA. 2005. Environmental evaluation and development problems of the Mexican Coastal zone. Ocean and Coast Manage 48: 161-176.

Magalhães A, Leite N da R, Silva JG, Pereira LCC AND CostA RM DA. 2009. Seasonal variation in the Copepod community structure from a tropical Amazon. An Acad Bras Cienc 81: 187-197.

MARENGO J. 1995. Interannual variability of deep convection in the tropical South American sector as deduced from ISCCP C2 data. Int J Climatol 15(9): 995-1010.

Martinelli JM, Giarrizzo T, Estácio J, Almeida TCB, DitTMAR T AND IsAAC VJ. 2002. Distribuição espacial do macrozooplâncton marinho na região costeira maranhense e paraense, Norte do Brasil. In: ANAIS DO WORKSHOP ECOLAB: ecossistemas costeiros amazônicos do conhecimento à gestão 6: 1-12.

Martorano LG, Pereira LC, Cezar EGM and PereiRA ICB. 1993. Estudos Climáticos do Estado do Pará: Classificação Climática (KÖPPEL) e deficiência Hídrica (Thornhtwhite, Mather). Belém, SUDAM/EMBRAPA/ SNLCS.

MazdA Y, Kanazawa N AND Wolanski E. 1995. Tidal asymmetry in mangrove creeks. Hydrobiology 295: 5158.

MeAde RH, Dune T And Richey JE. 1985. Storage and remobilization of suspended sediment in the lower Amazon River of Brazil. Science 228: 488-490.

Monteiro MC, Pereira LCC And Oliveira SMO DE. 2009. Morphodynamic changes of a macrotidal sand beach in the Brazilian Amazon coast (Ajuruteua-Pará). J Coastal Res SI56: 103-107.
Moraes BC De, Costa JMN DA, Costa ACL DA AND Costa MH. 2005. Variação espacial e temporal da precipitação no estado do Pará. Acta Amazon 35: 207-214.

ÖRNÓlfSDÓtTIR EB, LUMSDEN SE AND PINCKNEY JL. 2004. Phytoplankton community Growth rate response to nutrient pulses in a shallow turbid estuary, Galveston Bay, Texas. J Plankton Res 26(3): 325-339.

Pereira lCC, Jiménez JA, Koening ML, Porto Neto F, Medeiros C And Costa RM DA. 2005. Effect of coastline properties and wastewater on plankton composition and distribution in a stressed environment on the north coast of Olinda-PE (Brazil). Braz Arch Biol Techn 48(6): 1013-1026.

Pereira lCC, Medeiros C, Jiménez JA and Costa RM DA. 2007a. Use and Ocupation in the Olinda littoral (NE, Brazil): Guidelines for an Integrated Coastal Management. Environ Manageme 40: 210-218.

Pereira lCC, Guimarães Do, Ribeiro MJS, Costa RM AND Souza Filho PWM. 2007b. Use and occupation in Bragança littoral, Brazilian Amazon. J Coastal Res SI50: 1116-1120.

Pereira LCC, Ribeiro CMM, Monteiro MC AND AsP N. 2009. Morphological and sedimentological changes in a macrotidal sand beach in the Amazon littoral (Vila dos Pescadores, Pará, Brazil). J Coastal Res SI56: 113-117.

RICARD M. 1987. Atlas du phytoplancton Marin. 2: Diatomophycées. Centre National de la Recherche Scientifique, Paris, 297 p.

Silva IR, Pereira LCC And Costa RM. 2006. Uso e Ocupação em uma comunidade pesqueira na margem do estuário do rio Caeté (PA, Brasil). Desenvol e Meio Amb 13: 11-18.

Silva IR da, Pereira lCC, Guimarães D de O, TrinDAdE WN, Asp N ANd Costa RM DA. 2009. Environmental Status of Urban Beaches in São Luís (Amazon Coast, Brazil). J Coastal Res SI56: 1301-1305.

SMAYdA TJ. 1980. Phytoplankton species succession. In: MORRIS I (Ed), Berkeley, University of California Press, p. $493-570$.

SMAYDA TJ. 2002. Turbulence, watermass stratification and harmful algal blooms: an alternative view and frontal zones as "pelagic seed banks". Harmful Algae 1: 95-112.

SmetaceK V. 1998. Plankton characteristics. In: Postma H ET AL. (Eds), Ecosystems of the World: Continental Shelf. Amsterdam: Elsevier 27(4): 93-130.

SokAL RR AND RohlF FJ. 1969. Biometry. W.H. Freeman \& Co, San Francisco, California, USA, 776 p. 
SournIA A. 1975. Phytoplankton Manual, UNESCO Monographs on Oceanographic Methodology 6.

Sousa EB de, Costa VB da, Pereira LCC And Costa RAAM DA. 2008. Microfitoplâncton de Águas Costeiras Amazônicas: Ilha Canela (Bragança-Pará-Brasil). Acta Bot Bras 22: 629-636.

Souza Filho PWM, Martins ESF And Costa FR. 2006. Using mangroves as a geological indicator of coastal changes in the Bragança macrotidal flat, Brazilian Amazon: A remote sensing data approach. Ocean and Coast Manage 49: 462-475.

StATSoft. 2001. Statistic (Data analysis software system), version 6. <http://www.statsoft.com >.

STEFFY LY AND KILHAM SS. 2006. Effects of urbanization and land use on fish communities in Valley Creek watershed, Chester County, Pennsylvania. Urban Ecosystem 9: 119-133.

STRICKLAND JDH AND PARSOns TRA. 1968. The Practical Handbook of Seawater Analysis. Bull Fish Res Board of Can 167: 1-311.
STRICKLAND JDH AND PARSONS TRA. 1972. Manual of Seawater Analysis. Bull Fish Res Board of Can 125: 1205.

Thompson B, Adelsbach T, Brown C, Hunt J, Kuwabara J, Neale J, Ohlendorf H, SchwarzBACH S, SpIES R AND TABERSKI K. 2007. Biological effects of anthropogenic contaminants in the San Francisco Estuary. Environ Res 105: 156-174.

Tilstone GH, Míguez BM, Figueiras FG and FerMIN EG. 2000. Diatom dynamics in a coastal ecosystem affected by upwelling: coupling between species succession, circulation and biogeochemical processes. Mar Ecol Prog Ser 205: 23-41.

Tomas CR. 1997. Identifying Marine Phytoplankton. Academic Press, San Diego.

Tundisi JG. 1970. O plâncton estuarino. Contr Avulsas Inst Oceano. São Paulo, Ser Ocean Biol 19: 1-22.

ZAR JH. 1999. Biostatistical Analysis. $4^{\text {th }}$ ed., Prentice Hall, New Jersey, USA, 663 p. 